Journal Of Agriculture and Social Research (JASR) Vol. 8, No.1, 2008

\title{
PREVALENCE OF TSETSE FLY AND BOVINE TRYPANOSOMOSIS IN THE BIOLOGICAL CONTROL OF TSETSE FLY PROJECT (BICOT) WITHIN LAFIA LOCAL GOVERNMENT AREA OF NASARAWA STATE, NIGERIA
}

\author{
OLUWAFEMI, R. A, ILEMOBADE, A. A AND LASEINDE, E. A. O
}

\begin{abstract}
The prevalence of tsetse fly and bovine trypanosomosis was studied in the biological control of tsetse fly project (BICOT) area within Lafia Local Government Area of Nasarawa state, Nigeria between May and November 2000. The project area, covering approximately $1500 \mathrm{~km} 2 \mathrm{was}$ virtually freed of Glossina palpalis palpalis and to some extent G tachinoides by Dec. 1984. By 1987, however, sterile male releases were suspended and remained so till the time of this study due to lack of funding. Ten biconical traps were set at an interval of 25 meters along each river/stream in the study area. In all, 466 flies were caught out of which 454 were G.p palpalis while the remaining 12 were G.tachinoides. The result of the dissection of the insects showed that 9 (1.9\%) of tsetse flies caught were positive for Trypanosoma vivax. All infected flies were G.p palpalis. Also blood samples were collected from 200 cattle in the abattoir and 200 in the sedentary cattle in the area. The blood samples were examined using standard parasitological techniques. The result showed that, in sedentary cattle, 18(9\%) were positive for trypanosomes while in the abattoir 21(10.5\%) were positive for trypanosomes. There was however no significant difference $(p>0.05)$ between the numbers of cases defected in sedentary cattle and abattoir cattle. Most of the infections in sedentary cattle (67\%) and abattoir cattle (81\%) were due to T. congolense.
\end{abstract}

Key words; Tsetse fly ,bovine trypanosomosis, biological control, Lafia

\section{INTRODUCTION}

Trypanosomosis is a serious, frequently fatal disease caused by single-celled parasites of the genus Trypanosoma. The trypanosome is transmitted by the bite of a tsetse fly to people and to wild and domestic animals (Anon, 1991). The most important are those that affect cattle in Africa; they are Trypanosoma vivax, T. congolense and T. brucei. The tsetse fly (genus: glossina) the vector of trypanosomosis occurs only in sub-Saharan Africa. In other parts of the world, the transmission of trypanosomes pathogenic to animals is believed to be non-cyclical or mechanical and is effected mainly by blood sucking arthropods (Anon, 1991). The essential difference between cyclical and non-cyclical transmission is that in the former case, tsetse flies form a reservoir of infection, a factor that complicates the epidemiology and control of the African animal trypanosomosis (connor, 1989).

Tsetse transmitted trypanosomosis is classified as severe in the majority of the 37 subSaharan countries affected, where is figures among the first three priority veterinary diseases (FAO, 1992). Tsetse flies invest about 10 million $\mathrm{km} 2$ of fertile land spread across 37 countries on the African continent from Senega in the North to South Africa in the South (PAAT,2001). Their economic and social impact is considerable, constraining livestock production and also arable farming where animals are not available for draught power. It has been found over the years that in a large number of African countries, agricultural development as a whole has fallen behind overall economic growth and the shortfall are particularly serious in the livestock sub-sector (Sabine, 1993).

A few breeds of livestock that are indigenous to Africa, such as the N'dama cattle of West Africa are able to tolerate trypanosomes, hence they are considered to be trypanotolerant (Murray et al,1982). However trypanotolerant N'Dama cattle can nevertheless suffer from trypanosomosis when subjected to high level of tsetse challenge (Mattoili et al 1998). The Zebu breeds, which are 
trypanosusceptible, can permanently inhabit the tsetse-infected zone only when supported by chemical prophylaxis or vector control (Anon, 1991). Tsetse and trypanosomosis situation in many parts of Nigeria has been severally reported by Kalu (1996,1997) Ilemobade et al (1991), Ilemobade, (1994) and Kalu and Lawani (1996) to mention but a few.

In contribution to these efforts, the present study was carried out to determine the present state of tsetse fly and bovine trypanosomosis in the Biological Control of Tsetse fly Project (BICOT) area in Lafia Local Government area of Nasarawa State. By the end of Dec. 1984, most of the target area had been virtually freed of G.p. palpalis and about $90 \%$ of G. tachinoides, but the sterile male releases in the field were suspended in November 1987 due to lack of funding (Anon 1988) despite the recommendation for the commencement of the second phase as contained in the report of Ilemobade et al, 1985.

\section{MATERIALS AND METHODS}

The study was carried out in the field unit of the biological control of tsetse fly project area, within Lafia Local government area of Nasarawa state Nigeria. Covering approximately $1500 \mathrm{~km} 2$, the area is one of the most productive agricultural zone of Nigeria. Nasarawa state was originally part of plateau state and is located next to the Federal Capital Territory of Abuja and in the central area of Middle Belt region along latitude $7 \mathrm{o} \mathrm{N}$ and longitude $10 \mathrm{oE}$. It is within the Guinea savanna vegetation Zone of Nigeria. The annual rainfall varies between $131.75 \mathrm{~cm}$ in some places to $145 \mathrm{~cm}$ in other places (Anon,1999).

Data for this study were obtained from the survey of tsetse fly and bovine trypamosomosis in the study area. The surveys for the prevalence of tsetse flies involve the use of 10 biconical traps, which were employed to cover each of the river/stream within the area on a 24-hour basis. The traps were set at designated sites along the river course. On the other hand, the survey for the prevalence of trypanosome infection in cattle was carried out through tsetse fly dissection and parasitological examination of blood samples collected from 200 sedentary cattle and another 200 from those slaughtered at the abattoirs and slaughter slabs in the study area. Tsetse flies caught were dissected daily during the study period to examine for the presence of trypanosomes in their system (mainly the proboscis, salivary gland and the mid-gut of the flies). Blood samples collected from both sedentary and slaughter cattle were also examined for the presence of trypanosomes using standard parasitological techniques.

\section{RESULTS AND DISCUSSION}

The total number of tsetse flies caught was 466 out of which 454 were Glossina palpalis palpalis while the remaining 12 were $G$. tachinoides. The results of the dissection showed that 9 $(1.9 \%)$ of the 466 flies were infected with trypanosomes, all being Trypanosoma vivax and from G.p. palpalis. The small number of $G$. tachinoides caught during the study period may be responsible for the absence of infection in this specie. The results of parasitological examination of blood samples on the other hand showed that, out of the 200 samples collected from sedentary cattle, and another 200 samples from slaughter cattle, 18(9\%) and $21(10.5 \%)$ were positive for various trypanosomes species respectively. All the three pathogenic trypanosomes were encountered in the study area during the study period. The breakdown showed that from sedentary cattle, $12(6.7 \%), 4(22.2 \%)$ and $2(11.1 \%)$, and from slaughtered cattle, $17(81 \%), 3(14.3)$ and 1 (4.8\%) were positive for Trypanosoma congolense, T. vivax and T. brucei respectively (Tables I and II ).

Table1.trypanosome infection in slaughtered cattle from abattoir and slaughter slabs in the study area. 
Journal Of Agriculture and Social Research (JASR) Vol. 8, No.1, 2008

\begin{tabular}{llllllll}
\hline S/no & Town/village & $\begin{array}{l}\text { Number } \\
\text { sampled }\end{array}$ & $\begin{array}{l}\text { Number } \\
\text { positive }\end{array}$ & $\begin{array}{l}\text { T. } \\
\text { congolense }\end{array}$ & $\begin{array}{l}\text { T. } \\
\text { vivax }\end{array}$ & $\begin{array}{l}\text { T. } \\
\text { brucei }\end{array}$ & mixed \\
\hline 1 & Lafia & 50 & 6 & 4 & 2 & 0 & 0 \\
2 & Adogi & 25 & 2 & 2 & 0 & 0 & 0 \\
3 & Assakio & 20 & 3 & 3 & 0 & 0 & 0 \\
4 & Maiakuya & 20 & 1 & 1 & 0 & 0 & 0 \\
5 & Akura & 35 & 4 & 2 & 1 & 1 & 0 \\
6 & Bakin-rigia & 20 & 2 & 2 & 0 & 0 & 0 \\
7 & Agyaragu & 20 & 3 & 3 & 0 & 0 & 0 \\
& Total & 200 & $21(10.5 \%)$ & $17(81 \%)$ & $3(14.3 \%)$ & $1(4.8 \%)$ & \\
\hline
\end{tabular}

Table 2: Trypanosome infection in sedentary cattle in the study area.

\begin{tabular}{llllllll}
\hline S/no & Town/village & $\begin{array}{l}\text { Number } \\
\text { sampled }\end{array}$ & $\begin{array}{l}\text { Number } \\
\text { positive }\end{array}$ & $\begin{array}{l}\text { T. } \\
\text { congolense }\end{array}$ & $\begin{array}{l}\text { T. } \\
\text { vivax }\end{array}$ & $\begin{array}{l}\text { T. } \\
\text { brucei }\end{array}$ & mixed \\
\hline 1 & Adogi/kirayi/tsakwa & 30 & 2 & 2 & 0 & 0 & 0 \\
2 & Wakwa/Bakin-rigia & 20 & 1 & 1 & 0 & 0 & 0 \\
3 & Akura/Feferuwa & 30 & 4 & 3 & 1 & 0 & 0 \\
4 & Ganye/Chiba & 25 & 2 & 1 & 1 & 0 & 0 \\
5 & Assakio/Maiakuya & 25 & 2 & 1 & 0 & 1 & 0 \\
6 & Shabu/Awuma & 20 & 2 & 1 & 2 & 0 & 0 \\
7 & Bukankwato & 20 & 1 & 1 & 0 & 0 & 0 \\
8 & Lafia & 30 & 3 & 2 & 0 & 1 & 0 \\
& Total & 200 & $18(9 \%)$ & 12 & 4 & 2 & 0 \\
& & & $(66.7 \%)$ & $(22.2 \%)$ & $(11.1 \%)$ & \\
\hline
\end{tabular}

The present study indicates that tsetse and trypanosomosis are still of much concern and represents a major obstacle to livestock production and development of allied industries. The study further revealed that G.p. palpalis that was eradicated from the study area about two decodes ago (Anon. 1985) have again become established in the area. This clearly showed that in spite of the efforts made and the financial commitments to the fight against tsetse and trypanosomosis in the study area, the disease is still prevalent. Unless a genuine policy and realistic measures as regards tsetse and trypanosomosis control are accorded due priority, the situation will persist or probably increase in the nearest future.

The presence of infected Glossina in the area indicates that the transmission cycle has not been broken. This situation will continuously create a trypanosomosis problem in the area. That the infection in tsetse flies caught during the study period is low, is in agreement with leak (1999) which says that tsetse species differ in their capacity to acquire and transmit trypanosomes, with palpalis group species being poor vectors of most trypanosome species. However, despite the low vectorial capacity of this species of Glossina, their economic important role in maintaining the transmission cycle cannot be over emphasized. All the three pathogenic trypanosome species found in cattle were encountered during this study, with Trypanosoma congolense being the most prevalent followed by $T$. vivax and T. brucei. This is in agreement with the findings of other researchers (Ilemobade, 1994, Onyiah, 1997 and Ajayi et al, 1997).

Earlier reports from the study area from 1982 to 1985 stated that the overall prevalence of bovine trypanosomosis in sedentary herd was $11.8 \%$ (Anon, 1985). In comparison with the findings of this study, there appears to be no significant difference because the present study revealed an overall prevalence of $9 \%$. A number of factors however is responsible for this unhealthy situation, 
prominent among which is the lack of consolidation of the achievement recorded in the first phase of the BICOT project.

\section{CONCLUSION}

The rate of tsetse reinvasion as revealed by the present study shows that unless there is deliberate intervention, there will be a continuous build up of tsetse population. The threat of trypanosomosis can be removed once and for all by the eradication of the vector. This has been achieved in the past especially in the study area using sterile insect technique (SIT). Concerted effort is therefore needed generally in the country towards the control of tsetse flies and trypanosomosis.

\section{REFERENCES}

Ajayi, S.A, Ogedengbe, J.D., Dogo. G.I and Ogunote, M. E (1997) Monitoring of Tsetse and trypanosomosis control programme in plateau and Bauchi States of Nigeria using Elisa related techniques (reacting abstract No 37). Nigerian Society for parasitology Abstract. 1997 40pp.

Anon (1999). Brief on Nasarawa State. A paper presented by the Permanent Secretary, ministry of information, youth, sports and culture on the occasion of the study tour of course 21, senior division of command and staff college, Jaji to Nasarawa State, 25-29 January 1999.

Anon (1991). ILRAD annual scientific report pp.35-39

Anon (1988). BICOT project annual report.

Anon (1985). BICOT project annual report.

Connor, R. T. (1989). Final report of the regional Trypanosomosis expert. Regional Tsetse and Trypanosomosis control programme, Malawi, Mozambique, Zambia and Zimbabwe, December (1989). FGU-Krobeg Konigstefin, West Germany.

FAO (199). The influence of trypanosomosis on African animal production. Animal zootechnia pp $1-2$

Ilemobade, A.A (1994) Prevalence studies of bovine trypanosomosis in Nigeria. A report of a survey carried out on the prevalence of bovine Trypanosomosis in Nigeria commissioned by the Federal livestock Department, Lagos, Nigeria. 44pp.

Ilemobade,A.A,Ogunyemi,O.,David-West.K.B and Onyia V.C. (1991). A survey of the continued prevalence and importance of cattle trypanosomosis in Nigeria. In OAU/STRC pp.292-294

Ilemobade, A.A., Gadzama, N.N, LeRoux, J. G., Turner, D.A, Voh, J.P and Joshua, R.A. (1985) Report of the review panel on Biological control of tsetse fly by sterile insect technique (BICOT). $43 p p$

Kalu, A.U. (1997). Epidemiology of ruminant trypanosomosis in sleeping sickness endemic areas of Nigeria. Ph. D Thesis, University of Nigeria Nsukka 186pp.

Kalu, A.U (1996) Acute Trypanosomosis in a sedentary herd on the tsetse free Jos plateau, Nigeria. British Veterinary journal 152 (4) p 477-479. 


\section{Journal Of Agriculture and Social Research (JASR) Vol. 8, No.1, 2008}

Kalu, A.U. and Lawani, F. A. (1996). Observation on the epidemiology of Ruminant trypanosomosis in Kano State, Nigeria. Revue d'elevage et de medecine veterinaire des pays tropicaux, 49 (3) 213-217

Leak,S.G.A (1999) Tsetse biology and Ecology; their role in the epidemiology and control of trypanosomosis, CABI Publishing, U.K. $56 \mathrm{pp}$.

Mattoili,R.C., Jaitner, J., Clifford, D.J., Pandey, V.S and Verhulst,A(1998) Trypanosome infection and tick infestation; susceptibility in N'Dama, Gobra Zebu and Gobra X N'dama crossbreed cattle exposed to Natural challenge and maintained under high and low surveillance of trypanosome infection. Acta Tropical 71: 57-71

Murray. M., Morrison, W.I and Whitelaw, D.D (1982). Host susceptibility to African trypanosomosis; trypanotolerant. Advanced Parasitology. 21; 1-68

Onyiah, J. A. (1997). African Animal trypanosomosis: An overview of the current status in Nigeria. Tropical veterinary journal, volume, 111-116.

Sabine, N. (1993). Trypanosomosis assessment, Tsetse biology and tsetse control. A paper presented at the FAO/TTC training course for middle level personnel. ITC, the Gambia, 126, March.

PATTEC (2001) Pan African Tsetse and Trypanosomiasis eradication Campaign: enhancing Africa s Prosperity, 30pp 